\title{
SCIENTIFIC EXPLANATION OF COMPOSITION OF ACIDOPHILIC-WHEY ICE CREAM, ENRICHED WITH PROTEIN
}

\author{
Galina POLISCHUK ${ }^{1}$, Oksana KOCHUBEY-LYTVYNENKO ${ }^{1}$, Tetiana OSMAK ${ }^{1}$, \\ Uliana KUZMIK ${ }^{1}$, Oksana BASS, Artur MYKHALEVYCH ${ }^{1}$, * Victoria SAPIGA ${ }^{1}$ \\ Educational and Research Institute of Food Technology, National University of Food Technologies, \\ 01601,Volodymyrska str.68,Kyiv, Ukraine, vika.sapiga1904@ukr.net \\ *Corresponding author \\ Received $6^{\text {th }}$ November 2020, accepted 30 $0^{\text {th }}$ March 2021
}

\begin{abstract}
The work is devoted to solving the actual problem of the dairy industry - complex processing of food raw materials, expanding the range of dairy and milk-containing products of high nutritional value due to enrichment of protein, pro- and prebiotics, rational use of production resources by reducing the the technological process duration.

The aim of the research is to substantiate the composition of a new type of acidophilic-whey ice cream of high nutritional value due to enrichment with a complex of proteins, probiotic sourdough and pectin-containing vegetable paste.

The main tasks of scientific work are: development of a scientifically based formulation for a new type of ice cream to expand the range of products that will improve the nutrition structure of the Ukraine 's population.

The methods used to study the organoleptic and physico-chemical indicators of blends and ice cream are well known and presented in the article.

The method of production of sour milk ice cream and the choice of dairy raw materials for obtaining a fermented base was theoretically substantiated, the functional and technological properties of protein concentrates and their compositions in ice cream formulations were studied, the rational content of protein in ice cream was established, also the expediency of using pectin-containing vegetable paste in acidophilic-whey ice cream was proved.
\end{abstract}

Keywords: acidophilic-whey ice cream, probiotics, prebiotics, protein, pectin-containing purees

\section{Introduction}

Ice cream is a product popular with all segments of the population, especially among children. But this dessert product is not low in calories. Therefore, nutritionists do not recommend using it for overweight children. The share of sugar in ice cream is quite high - from 14 to $30 \%$, and the fat content in ice cream is in the range from 8 to $20 \%$. At the same time, in recent years in the scientific works of many Ukrainian and foreign scientists much attention is paid to the production of low-calorie foods $[1,2]$.

In EU countries, the nutritional value of products indicated on the label is regulated by the relevant regulation [3]. According to this document, a low-fat product should contain no more than $3 \mathrm{~g}$ of fat per $100 \mathrm{~g}$ of product, and a product with a low sugar content should be $30 \%$ less sugar than a similar product with a full content.

Instead, the range of domestic ice cream is mainly high-fat products of creamy and plombieres groups, although the world's 
demand for low-calorie milk ice cream is growing every year. However, in the case of fat content decrease in the milk ice cream, there are defects of consistency in the form of coarse-grained structure and heterogeneous air phase [4]. That is why to prevent such a defect in consistency in milk formulas additionally add moisturebinding components, including proteins and polysaccharides [5].

The range of ice cream with probiotics, non-fat and low-fat in Ukraine is extremely limited (yogurt, cottage cheese ice cream), and ice cream enriched with proteins and prebiotics is completely absent [6]. Therefore, instead of milk as a dairy base in the composition of ice cream, it is advisable to use fermented probiotic acidophilic yeast secondary dairy resources - skimmed milk, buttermilk and whey, which contain biologically complete proteins and can be further enriched with pectin-containing raw materials. In view of the above, research on the expansion of the range of low-calorie ice cream of high nutritional value is a very relevant area of research.

\section{Matherials and methods}

\subsection{Materials}

The following raw materials, that met the requirements of current standards, were used for research: whole milk - DSTU 3662-2018, buttermilk and whey obtained during the production of sweet butter by the method of HFC conversion and natural rennet cheese from whole milk according to DSTU 3662-20018, sugar - DSTU 4623:2006, drinking water - GOST 287482, skimmed milk powder - DSTU 4273:2003, buttermilk powder - DSTU 4555:2006, whey powder - DSTU 4552:2006, fresh vegetables according to GSTU 7033:2009 and DSTU 8147:2015, starter on pure cultures of Lactobacillus acidophilus ("Iprovit"), sodium caseinate (firm "DeiriCo", Lutsk casein plant, Ukraine) integrated stabilization system Cremodan SE 406 (firm "Danisco", Denmark) - according to the conclusions of the sanitary-hygienic issued by the central executive body for health care of Ukraine.

\subsection{Methods}

Resistance to melting was determined by a modified method. For research, before sampling, the samples were subjected to short-term warming at a temperature of 20 ${ }^{\circ} \mathrm{C}$ for 15 minutes. The formed ice cream cylinders with a height of $50 \mathrm{~mm}$ and a diameter of $35 \mathrm{~mm}$ were placed on perforated plastic stands mounted on tripods. Under the tripods were measuring cylinders with a capacity of $100 \mathrm{~cm}^{3}$, into which the liquid fraction flowing from the ice cream samples fell through the funnels. Using a special tripod, the digital camera was statically fixed and the samples were photographed at a temperature of $20^{\circ} \mathrm{C}$ for 60 minutes. The time of appearance of the first drop of "melt" and the time of outflow from the ice cream sample of $10 \mathrm{~cm}^{3}$ "melt" were recorded.

Overrun (S), \%, of ice cream was determined by weight and calculated according to the formula:

$$
S=\frac{m_{m}-m}{m} \times 100
$$

where $m_{m}-$ mass of ice cream blend of a certain volume, $\mathrm{g}$;

$m$ - the mass of ice cream of the same volume, $g$.

The size of the air bubbles was determined by the method of ASRRI (All-Russian Scientific Research Institute of Refrigeration Industry). The ice cream sample was applied to the calibrated grid of Goryaev's chamber, covered with a cover glass and immediately microscopied at 160 times magnification. The ice crystals melted, but the foam remained, 
because under these conditions, the air bubble shells were not dehydrated.

The count was performed in five to seven fields of view. By the number of groups n, the weighted average diameter of the air bubbles for each preparation $d_{a v}$ was calculated according to the formula:

$$
\mathrm{d}_{\mathrm{av}}=\sqrt[3]{\sum_{1}^{n} d_{i}^{3}} \frac{N}{N_{i}}
$$

where $d_{i}-$ the average diameter of air bubbles in each group, $\mu \mathrm{m}$;

$N_{i} \quad$ - the number of bubbles in each group;

$\mathrm{N}$ - total amount of bubbles in all groups.

Organoleptic evaluation of ice cream samples was performed by tasting. Determination of organoleptic properties was carried out using qualitative and quantitative methods. Qualitative assessment of ice cream was expressed in a verbal description of its taste, smell, structure and consistency, in quantitative assessment organoleptic indicators were reflected in a certain amount of points, according to the 100-point system with the accepted distribution of significance of its individual indicators: taste, smell and aroma - 60 points, structure and consistency - 30 points, color and appearance - 10 points. According to the total number of ice cream was attributed to one of the varieties: extra - from 96 to 100 points; the highest - from 91 to 95 points; the first - from 80 to 90 points.

\subsection{Preparation of experimental samples}

Separately prepared sour milk base from skimmed milk, buttermilk and whey. For this purpose, dry dairy raw materials was restored in liquid dairy raw materials, the blend was filtered and heated to a temperature of $70 \pm 2{ }^{\circ} \mathrm{C}$, pasteurized at a temperature of $80 \ldots 85^{\circ} \mathrm{C}$ for $15-20 \mathrm{~s}$, cooled to $40 \ldots 42{ }^{\circ} \mathrm{C}$, inoculationed with starter of Lactobacillus acidophilus, incubationed for 3-4 $\mathrm{h}$ at a temperature of $42 \ldots 43^{\circ} \mathrm{C}$ to obtain a clot with a $\mathrm{pH}$ of not less than 4.1 , followed by cooling to a temperature not exceeding $6{ }^{\circ} \mathrm{C}$.

Separately in water at a temperature of 40 ${ }^{\circ} \mathrm{C}$ was made stabilizer with sugar in a ratio of $1: 3$ and the remaining sugar, the blend was pasteurized at a temperature of $82 \ldots 85^{\circ} \mathrm{C}$ for $15-20 \mathrm{~s}$, cooled to $10^{\circ} \mathrm{C}$, after-cooled and matured at $4 \ldots 6^{\circ} \mathrm{C}$ for 4 h. Homogenization was excluded from the technological scheme in the absence of fatcontaining components, except for the preparation of the control sample. Before freezing, the fermented acidophilic base was mixed with the main mixture. Freezing, hardening, re-hardening and storage of ice cream was carried out according to the classical scheme.

\subsection{The statistical analysis}

The obtained measurement results were calculated using standard statistical processing programs Microsoft Excel. Graphical representation of experimental data was performed using Microsoft Excel. The accuracy of the results was ensured by three to five times the repetition of the experiments.

\section{Results and discussion}

Samples of sour milk ice cream without filler with mass fraction of fat $2.8 \%$ (control) and acidophilic low-fat ice cream based on protein-carbohydrate raw materials (PHRM) - skimmed milk, buttermilk and whey - were prepared according to the typical formulations of yogurt ice cream [7]. It was used starter of direct entering (DVS-starter), so its weight was not taken into account.

In order to explain the significant difference in the quality indicators of the studied ice cream samples, the total milk protein content and its percentage in the 
DSMR of each ice cream sample were calculated (Table 1).

Table 1.

Mass fraction of protein in samples of acidophilic ice cream and its percentage content in the DSMR of product, $\%$

\begin{tabular}{|l|l|c|c|c|}
\hline \multirow{2}{*}{ Protein content: } & \multicolumn{4}{|c|}{ Sample name } \\
\cline { 2 - 5 } & $\begin{array}{l}\text { ice cream on } \begin{array}{r}\text { on } \\
\text { normalized } \\
\text { (control) }\end{array} \\
\text { milk }\end{array}$ & $\begin{array}{l}\text { ice cream on } \\
\text { skimmed milk }\end{array}$ & $\begin{array}{l}\text { ice cream on } \\
\text { buttermilk }\end{array}$ & ice cream on whey \\
\hline in ice cream, \% & 3.23 & 3.09 & 2.55 & 1.28 \\
\hline in DSMR of ice cream,\% & 37.13 & 35.52 & 29.31 & 14.71 \\
\hline
\end{tabular}

According to table. 1, it becomes clear that in the case of PHRM mass fraction of milk protein in ice cream (compared to the control sample) is gradually reduced. In the case of using whey as a milk base, the protein content decreases most significantly - from $3.23 \%$ (control) to $1.28 \%$ (whey ice cream) while a significant shift towards the predominance of DSMR, lactose and mineral salts - from 62,87 , $64,48,70,69 \%$ (for ice cream on normalized milk, skimmed, buttermilk) to $85.29 \%$ (for whey ice cream). Therefore, whey ice cream itself is most in need of enrichment with milk protein concentrates in the absence of an effective biopolymer a protein that binds free water, structures mixtures and stabilizes the structure of ice cream.

At the next stage of work, in order to identify the rational content of protein concentrates in acidophilic-whey ice cream, was investigated the possibility of enriching the product with sodium caseinate (SC), concentrate of whey proteins obtained by ultrafiltration (CWPUF) and soy protein isolate (SP). To enrich the experimental samples of ice cream, the content of milk-protein concentrates in the range from 0.75 to $3.75 \%$ with a step of $0.75 \%$ was selected.

The overrun of acidophilic-whey ice cream with the content of different protein concentrates is shown in Figure1.

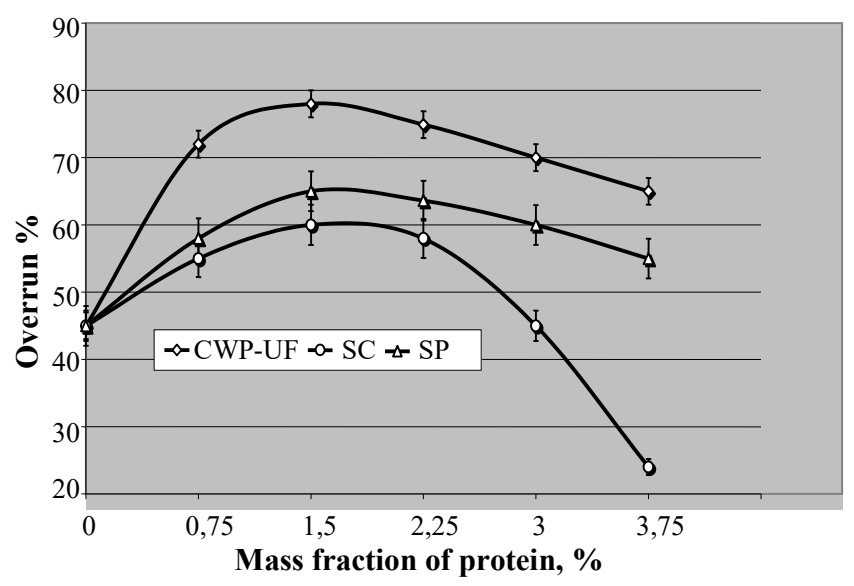

Fig. 1 - The overrun of acidophilic-whey ice cream, enriched with proteins of various origins

According to the results of the study (Fig. 1), it was found that the most technologically efficient foaming agent is CWP-UF ( $78 \%$ overrun), and the overrun

Galina POLISCHUK, Oksana KOCHUBEY-LYTVYNENKO, Tetiana OSMAK, Uliana KUZMIK, Oksana BASS, Artur MYKHALEVYCH, Victoria SAPIGA, Scientific explanation of composition of acidophilic-whey ice cream, enriched with protein, Food and Environment Safety, Volume XX, Issue 1 - 2021, pag. 13 - 20 
of blends with SP and SC was 65 and $60 \%$, respectively.

Resistance to melting of acidophilic-whey ice cream with the content of various protein concentrates is shown in Figure 2.

Resistance to melting of ice cream with sodium caseinate (Fig. 2) was the highest and slightly decreased for the sample with CWP-UF and was the lowest for the sample with soy protein.

The average diameter of air bubbles of acidophilic-whey ice cream with the

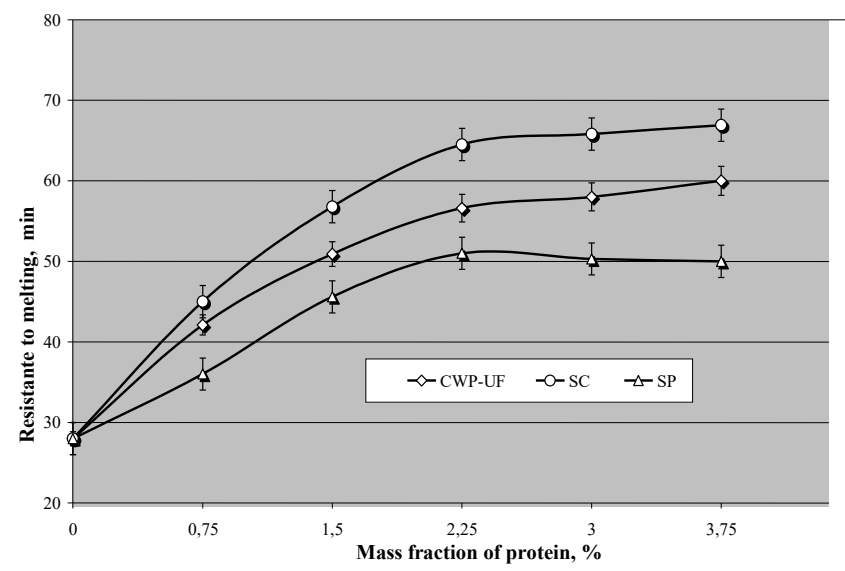

Fig. 2 - Resistance to melting of acidophilic-whey ice cream enriched with proteins of various origins

Thus, according to the results of the analysis of functional and technological characteristics of proteins, it is possible to recommend the mass fraction of CWP-UF (on average $215 \mathrm{UAH} / \mathrm{kg}$ ) at the level of $1.0-1.5 \%$, and the content of SC (275 $\mathrm{UAH} / \mathrm{kg}$ ) in the composition of ice cream, due to the manifestation of alkaline taste, despite its other advantages, should be used in an amount not exceeding $0.75 \%$.

Cheaper soy protein isolate (about 145 $\mathrm{UAH} / \mathrm{kg}$ ), as well as CWP-UF, can be recommended in the amount of about 1.0$1.5 \%$, although this protein is less effective in acidophilic-whey ice cream.

Therefore, if necessary to enrich acidophilic-whey ice cream with protein in an amount of not less than $2.75 \%$, it is content of different protein concentrates is shown in Figure 3.

The best dispersing agent that provides a fine distribution of the air phase in ice cream is $\mathrm{SC}$ with a slight decrease in this indicator for CWP-UF and for SP (Fig. 3). Sodium caseinate as a functional and technological ingredient in ice cream mixes improves their structure and consistency, binds part of the free water in the mixes, increases the dispersion of air bubbles.

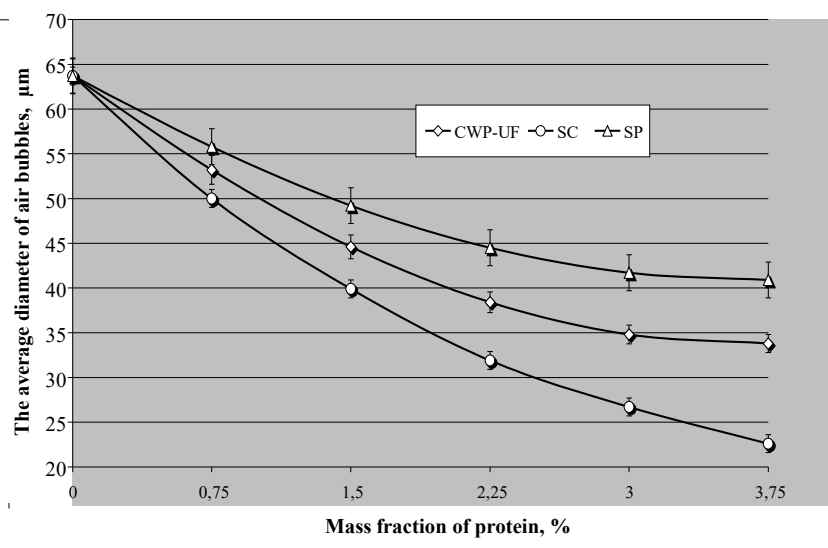

Fig. 3 - The average diameter of air bubbles of acidophilic-whey ice cream enriched with proteins of different origins

advisable to use the following protein composition:

- $0.75 \%$ SC (the most effective moisturebinding stabilizing high-value protein);

- 1.0-1.5\% CWP-UF (protein with foaming ability);

- $1.0-1.5 \%$ SP (cheap protein with moderate technological activity).

Protein compositions at the lower and upper limits of the components content are as follows:

- SC + CWP-UF + SP $=0.75 \%+1.0 \%+$ $1.0 \%=2.75 \%$;

$-\mathrm{SC}+\mathrm{CWP}-\mathrm{UF}+\mathrm{SP}=0.75 \%+1.0 \%+$ $1.5 \%=3.25 \%$;

$-\mathrm{SC}+\mathrm{CWP}-\mathrm{UF}+\mathrm{SP}=0.75 \%+1.5 \%+$ $1.5 \%=3.75 \%$.

When using the first composition, the protein content in ice cream with the status 
of "protein enriched" will be $4.0 \%$, the second composition $-4.5 \%$, and the third $5.0 \%$, which should be indicated in the product label and taken into account in marketing advertising.

At the next stage, to give acidophilic-whey ice cream original organoleptic properties, in particular, color, taste and consistency, it was decided to add additional vegetable paste (beetroot + broccoli at a ratio of 1:1), the technology of which was developed at the Department of Milk and Dairy Products Technology, NUFT [8]. Due to the probable interaction between milk proteins and soluble pectin of vegetables in the paste [9] it is possible to improve the structure of ice cream, which requires additional confirmation.

On the example of the recipe based on fresh cheese whey with the third composition of protein concentrates $(\mathrm{SC}+\mathrm{CWP}-\mathrm{UF}+\mathrm{SP}=0.75 \%+1.5 \%+1.5 \%=$ $3.75 \%$ ) (table 2) was established rational the content of vegetable paste in the composition of acidophilic-whey ice cream. To do this, was investigated a set of quality indicators of ice cream samples with a mass fraction of paste from 5 to $15 \%$, compared with the sample without vegetable filler (control).

Table 2.

Formulations of experimental samples of acidophilic-whey ice cream, enriched with a complex of proteins with different content of vegetable paste, $\mathrm{kg}$ per $1000 \mathrm{~kg}$ (excluding losses) *

\begin{tabular}{|c|c|c|c|c|}
\hline \multirow{2}{*}{$\begin{array}{l}\text { Formulation } \\
\text { component }\end{array}$} & \multicolumn{4}{|c|}{ Ice cream samples with mass fraction of vegetable paste, $\%$} \\
\hline & 0 (control) & $5($ sample 1$)$ & 10 (sample 2) & 15 (sample 3) \\
\hline $\begin{array}{l}\text { Cheese whey (mass } \\
\text { fraction of dry matter } \\
-\quad 6.1 \% \text {, mass } \\
\text { fraction of protin - } \\
0.6 \% \text {, mass fraction } \\
\text { of lactose }-4.5 \% \text { ) }\end{array}$ & $\begin{array}{c}783.5 \\
(0.47 \% \text { of protein })\end{array}$ & $\begin{array}{c}733.5 \\
(0.44 \% \text { of protein })\end{array}$ & $\begin{array}{c}683.5 \\
(0.41 \% \text { of protein })\end{array}$ & $\begin{array}{c}633.5 \\
(0.38 \% \text { of protein })\end{array}$ \\
\hline Sodium caseinate & 7.5 & 7.5 & 7.5 & 7.5 \\
\hline CWP-UF & 15.0 & 15.0 & 15.0 & 15.0 \\
\hline Soy isolate & 15.0 & 15.0 & 15.0 & 15.0 \\
\hline $\begin{array}{l}\text { White crystalline } \\
\text { sugar }\end{array}$ & 175.0 & 175.0 & 175.0 & 175.0 \\
\hline Vegetable puree & - & 50.0 & 100.0 & 150.0 \\
\hline $\begin{array}{l}\text { Stabilization system } \\
\text { SE } 406\end{array}$ & 4.0 & 4.0 & 4.0 & 4.0 \\
\hline Total: & 1000.0 & & & \\
\hline \multicolumn{5}{|c|}{ Characteristics of the finished product } \\
\hline $\begin{array}{l}\text { Mass fraction of dry } \\
\text { matter, not less } \\
\text { than, } \% \text {, of them: }\end{array}$ & 26.92 & 27.56 & 28.23 & 28.89 \\
\hline DSMR, not less & 9.02 & 8.66 & 8.33 & 7.99 \\
\hline sugar, not less & 17.5 & 17.5 & 17.5 & 17.5 \\
\hline protein, not less & 4.22 & 4.19 & 4.16 & 4.13 \\
\hline $\begin{array}{l}\text { dry matter of } \\
\text { vegetables, not less }\end{array}$ & - & 1.0 & 2.0 & 3.0 \\
\hline stabilizer, not less & 0.4 & 0.4 & 0.4 & 0.4 \\
\hline
\end{tabular}

Galina POLISCHUK, Oksana KOCHUBEY-LYTVYNENKO, Tetiana OSMAK, Uliana KUZMIK, Oksana BASS, Artur MYKHALEVYCH, Victoria SAPIGA, Scientific explanation of composition of acidophilic-whey ice cream, enriched with protein, Food and Environment Safety, Volume XX, Issue 1 - 2021, pag. 13 - 20 
Organoleptic and physico-chemical quality indicators of acidophilic-whey ice cream, enriched with a complex of proteins and vegetable filling, are shown in Fig. 4 and 5.

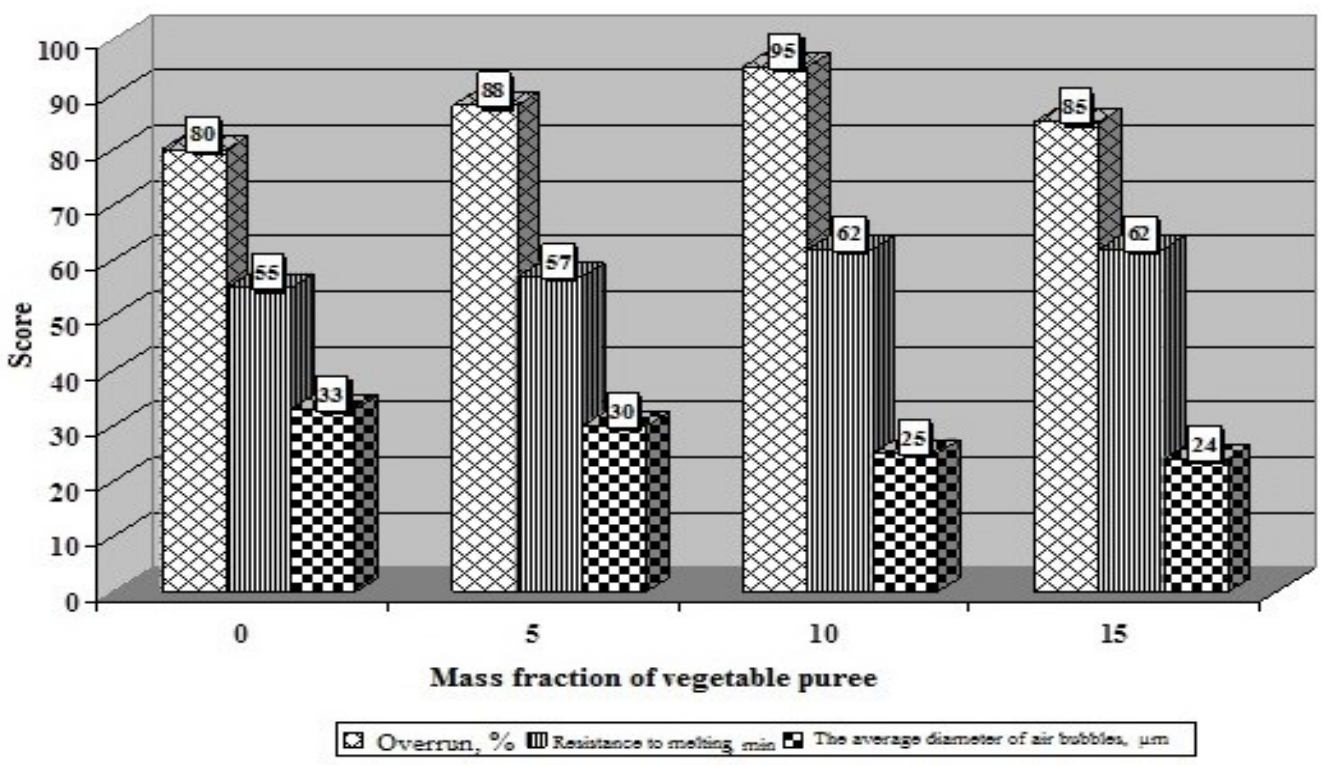

Fig. 4 - Physico-chemical parameters of acidophilic-whey ice cream, enriched with a complex of proteins with different content of vegetable puree

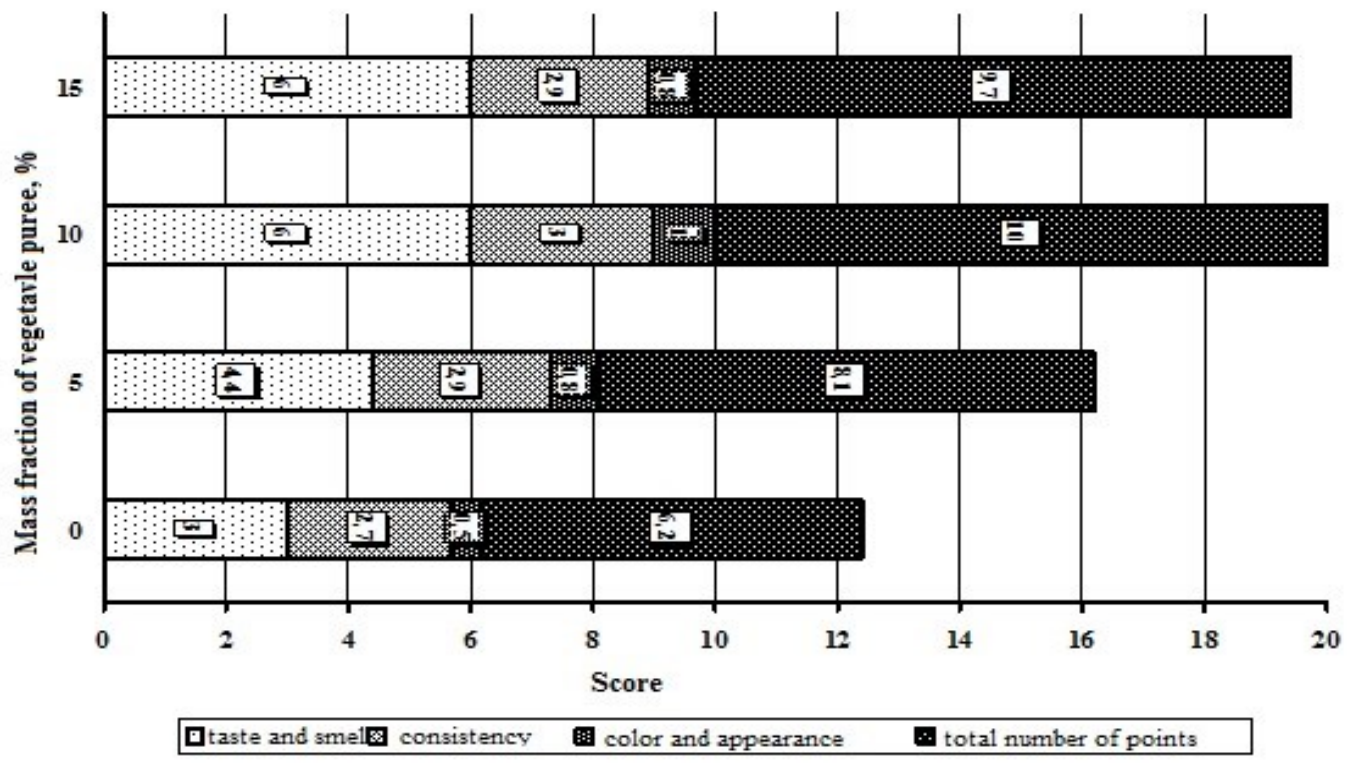

Fig. 5 - Score of organoleptic parameters of acidophilic-whey ice cream, enriched with a complex of proteins with different content of vegetable puree

Galina POLISCHUK, Oksana KOCHUBEY-LYTVYNENKO, Tetiana OSMAK, Uliana KUZMIK, Oksana BASS, Artur MYKHALEVYCH, Victoria SAPIGA, Scientific explanation of composition of acidophilic-whey ice cream, enriched with protein, Food and Environment Safety, Volume XX, Issue 1 - 2021, pag. 13 - 20 
According to fig. 4, the highest overrun was found at the content of vegetable paste at the level of $10 \%$, which is explained by the rational ratio between the foaming and stabilizing properties of the protein complex and pectin substances. A further increase in the content of the paste probably thickens the mixture too much, which complicates the process of saturating the mixture with air during freezing. The resistance to melting and dispersion of the air phase of ice cream with a increase in the paste content of more than $10 \%$ change slightly. Organoleptic characteristics of ice cream (Fig. 5) confirm the feasibility of adding $10 \%$ vegetable paste in formulation of acidophilic-whey ice cream, what significantly improves the taste and smell, turns the product pink, promotes the

\section{References}

[1]. SWINBURN B., CATERSON I., SEIDELL J., JAMES W.P. Diet, nutrition and the prevention of excess weight gain and obesity, Public Health Nutrition: 7(1A), pp.123-146.;

[2]. KAZAKOVA N.V., TVOROGOVA A.A. Influence of sucrose replacement by soluble dietary fibers on physical parameters of ice cream, Storage and processing of agricultural raw materials, № 11, 2007, P. 49-51.

[3]. Regulation (EC) No 1924/2006 of the European Parliament and of the Council of 20 December 2006 on nutrition and health claims made on foods

[4]. POLISHCHUK, G., BREUS, N., SHEVCHENKO, I., GNITSEVYCH, V., YUDINA, T., NOZHECHKINA-YEROSHENKO, G., SEMKO, T. Determining the Effect of Casein on the Quality Indicators of Ice Cream With Different Fat Content. Eastern-European Journal of Enterprise Technologies, 4/11 (106), 2020, P. 24-30.

[5]. RUDAKOVA T.V., MINOROVA A.V., \& NARIZHNY S.A. Innovative technologies of ice cream with functional ingredients, (2009). formation of a light creamy consistency. If the paste content exceeds more than $10 \%$, there is a slight decrease in creaminess also the ice cream is too bright and unnatural.

\section{Conclusion}

Thus, the expediency of protein complex using in acidophilic-whey ice cream has been scientifically proven, which in combination with vegetable paste due to the complexation between proteins and pectin and in the presence of insoluble dietary fiber of vegetables allows to obtain maximum technological effect. Low-fat ice cream, enriched with proteins, has improved organoleptic characteristics, as protein concentrates play the role of mimetics of milk fat.

[6]. TRUBNIKOVA, A., SHARAKHMATOVA, T., MAMINTOVA, K., \& TSUPRA, O. Biotechnological aspects of obtaining a yogurt base for the production of low-lactose ice cream. Bulletin of the National Technical University "KhPI". Series: New solutions in modern technologies, (9 (1285)), 2018, 243-255.

[7]. ARSENYEVA T.P. Handbook of dairy production technologist. Technologies and recipes. Vol.4. Ice cream - St. Petersburg: GIORD, 2002, $184 \mathrm{p}$.

[8]. SAPIGA V., SIZHKO D., POLISCHUK G., OSMAK T. Technological features of milk and vegetable ice cream production, 85th Jubilee International Scientific Conference of Young Scientists, Postgraduates and Students "Scientific Achievements of Youth - Solution problems of human nutrition in the XXI century ", April 11-12, 2019, K .: NUFT, - Part 1., 2019, p. 407.

[9]. PAVLYUK R. YU., POGARSKA V.V. Innovative technologies of vitamin fruit ice cream with the use of frozen fine additives from vegetable raw materials, East European Journal of Advanced Technologies. 4/10 (64), 2013, P. 57-63. 